\title{
Két megjegyzés az innovációról
}

Ez a rövid tanulmány egyrészt az innováció alapvető sajátosságaival, az innovációt meghatározó bizonytalanság természetével, az innovációhoz vezető tanulás sajátosságaival, valamint a neoklasszikus és az evolucionista közelítésmód alapfeltevéseinek szembeállításával, másrészt az áttörő vagy radikális innováció menedzselésével foglalkozik. A globalizáció körülményei között az innováció vizsgálata dinamikus rendszerszemlélet és evolucionista gondolkodás érvényesítését követeli meg. A tanulmány összehasonlítja az innovációról való neoklasszikus és evolucionista ökonómiai gondolkodás alapvető sajátosságait és összefoglalja, hogyan közelíti meg a radikális innovációmenedzselésének problémáját az evolucionista gondolkodásra építő ún. SOCROBUST-projekt.

Kulcsszavak: radikális innováció, bizonytalanság, neoklasszikus és evolucionista gondolkodásmód, SOCROBUST

\section{Szerzői információ:}

Hronszky Imre

Vegyész és filozófus, a filozófiai tudományok kandidátusa, 2000 óta a BME tanszékvezetố egyeteni tanára. 1998-ban habilitált. Oktatási és kutatási területei az innovációkutatás és a technikatörénet. Legfontosabb nemzetközi funkciójaként 1985-ben és 1986-ban az IUHPS Egyesített Bisottságának elnöki tisztét töltötte be. Számos könyv szerzôje és szerkesztôje a fenntartható ejlődés, a gazdasági globalizáció és a környezetvédelem, a kockázat és innováció, a társadalmi rontextusba helyezett technikai fejlódés, valamint az innovatív társadalomgazdaság és jövốtudat émaköreiben. Szakmai publikációi angol és német nyelvú nemzetközi folyóiratokban, valamint ıazai szaklapokban jelennek meg. Legfrissebb publikációja: Hronszky Imre - Kornwachs, Klaus eds.) (2006): Shaping Better Technologies. Münster: Litt. Verl.

E-mail: hronszky@eik.bme.hu

Így hivatkozzon erre a cikkre:

Hronszky Imre. „Két megjegyzés az innovációról”.

Információs Társadalom VI, 3. szám (2006): 9-28.

A folyóiratban közölt müvek 
Hronszky Imre

\section{Két megjegyzés az innovációról}

Ez a rövid tanulmány egyrészt az innováció alapvetô sajátosságaival, az innovációt meghatározó bizonytalanság természetével, az innovációhoz vezetô tanulás sajátosságaival, valamint a neoklasszikus és az evolucionista közelítésmód alapfeltevéseinek szembeállításával foglalkozik. Másrészt szemügyre veszi az áttörố innováció menedzselését.

\section{l/ Az innováció természetéről és adekvát kutatásának módjáról}

Az innovációt szokásos felosztani kis, illetve nagy innovációra. ${ }^{1}$ Noha ez lehetséges és fontos megkülönböztetés, bizonyos szempontból félrevezetô. Azt hiszem, hogy az innováció természete csak akkor ismerhetố meg adekvátan, ha nemcsak folytonosságot sugallunk a kis, illetve nagy innováció elnevezéssel, hanem amikor meg szeretnénk érteni az innováció természetét, a hangsúlyt inkább arra tesszük, amit nagy innovációnak neveznek. ${ }^{2}$ Kis innováció megvalósítása ugyanis lehetséges a meglevớ kompetenciák felhasználásával, kis javításokkal. Ekkor joggal támad a „szokásos üzletmenet” érzése. Kis innovációnál a kockázatok (viszonylag) jól kiszámíthatók, és sikeres innováció jön létre rutineljárások kis kiterjesztésével. A kis innovációk szerepe a gazdaság számára megjelenhet a lépték vagy a hatékonyság kis növelésében. A nagy innovációk szerepe a gazdaság számára viszont a léptékváltás, az irányváltás elốsegítése. A radikális innováció új út létrehozása (path creation), trajektória- vagy termékváltás. Jelentôsége a megjelenố radikálisan új lehetôségek felkínálásában és a gazdaság által való kiaknázásában van. Meglepő indikátorként érdemes észrevenni, hogy a nagy innováció megvalósításában a meglevő kompetenciák akár károsak is lehetnek, ha a szükséges felejtés hiánya miatt akadályozzák a szükséges új kompetencia megtanulását. A kockázatok nem csupán nem jól kiszámíthatók, hanem definíciónak tekinthetjük, hogy a nagy innovációk „eredeti meglepetést” jelentenek (az „eredeti meglepetésról” késóbb részletesebben írok). Ezért a kiszámítható kockázat menedzselése helyett a kiszámíthatatlan kockázat, a bizonytalanság racionális menedzselése kerül elótérbe.

\footnotetext{
${ }^{1}$ A kis innováció elnevezésében különböző szerzók a „folytonos”, „inkrementális”, „előállítás vagy használat során létrejövô", „a variációk fokozatos felhalmozódásához vezetón” és a „lineáris” jelzóket alkalmazzák. A nagy innováció jelzói különbözô szerzóknél: „áttörô”, „,architekturális”, „gyökeres”, „nem folytonos”, „szétzúzó” (disruptive), „,nem lineáris”.

${ }^{2}$ A kis innováció bitenként való folytonos javítás, ami viszonylag problémamentes. Ez a problémamentes javítgatás valamikor beleütközik egy punktuálisan megjelenő nagy innovációba úgy, hogy semmilyen meglevő skála vagy intenzitás növelése nem lesz már képes ezzel versenyben maradni.
} 
Adott radikális innováció kis innovációk formájában hosszú távon való „kimerítô” kiaknázása alapvető jellemzôje a „régi gazdaságnak”, akár az eljárás-, akár a termékfejlesztés normális szakaszában. Analógiával élve megvilágíthatjuk, hogy mi történik ekkor. A tudomány fejlődésének paradigmamodellje szerint a tudomány fejlôdése annak normáltudományos szakaszában azzal foglalkozik, hogy pontosítsa a paradigmát, illetve kiterjessze újabb és újabb esetekre. Ha bevezetjük a technológiai fejlődés paradigmamodelljét, akkor azt mondhatjuk, hogy a múszaki fejlesztésnek a paradigmadinamikájú fejlődésre jellemzố normális fejlődése során a paradigma pontosításáról, kiterjesztéséról és ezeknek az innováció számára való kihasználásáról van szó. ${ }^{3}$ Ez a kiaknázás elóbbutóbb „kimerítô” lesz. A kis innováció tipikus esetben „rejtvényfejtés” eredményeként oldódik meg. Ez a rejtvényfejtés a tudomány esetében azt jelenti, hogy tudjuk, hogy van megoldása a problémának, amit keresünk, esetleg még azt is tudjuk, hogy milyen megoldást keresünk, de meg kell találni a hozzá vezetô utat. Ugyanez jellemzó a múszaki fejlesztés kis innovációs problémáira. Az ilyen fejlődés tipikus volt a tömegtermelést megvalósító iparágak innovációs folyamataiban az elmúlt évszázadban, a 20. században, egészen annak utolsó negyedéig. Valamely adott iparág a múszaki (vagy szervezeti) fejlesztés során ragaszkodott a bevált paradigmához, ez mutatkozott gazdaságosnak, és kis innovációk kidolgozásával kiaknázta azt. Bizonyos fejlő́dési szakaszokban ennek folytatása már lehetetlenné vált (legalábbis lehetetlennek túnt), a paradigma kimerült, és paradigmaváltáshoz vezetố nagy innovációra, múszaki forradalmakra került sor.

A kis innováció hajtóereje egyaránt lehet a szükséglet, illetve a kereslet. A kis innováció többnyire meglevô szükséglet kielégítésére irányul, ugyanakkor könnyen kialakul iránta a szükséglet, ha már létrejött. Áttörő innováció esetében sokkal inkább az innováció és a fogyasztó koprodukciójától, koevolúciójáról van szó. ${ }^{4}$ Ez azt jelenti, hogy miközben az innováció a keletkezési folyamata során általában alapvetốen maga is formálódik, sikerre vitele strukturális változásokat követel meg a környezetében is. Ez a számára adekvát feltételrendszer kialakulása például a fogyasztói szokásrendszerben, az innovációhoz kapcsolódó szabályozásokban, a technológiatranszfer módjában stb. Erre a koevolúcióra - legalábbis jelzésszerûen - késóbb visszatérek.

Közhellyé vált, hogy a globalizációban döntôvé válik a kiélezett, az egész világra kiterjedt verseny. Ez az egyik oldalról a nem lineáris kapcsolatok döntôvé válását, a „súrú kölcsönhatás” tipikussá válását jelenti. Ilyen viszonyok között az a tapasztalat, hogy vesztő stratégia, ha arra törekszünk, hogy fenntartsuk a korábban tipikus, kis innovációkkal előrehaladó stratégia további dominanciáját, tehát vesztô stratégia az adott paradigmatikus fejlődési irány kis változtatásokkal történố és „túl hosszú” ideig tartó kiaknázására való törekvés. Döntốvé válnak-e ezzel a „nagy” innovációk, s arról van-e

\footnotetext{
${ }^{3}$ A tudományos paradigma kuhni koncepciója (1962) szerint a paradigmadinamika normális és forradalmi szakaszok váltakozásából áll. Kuhn nyomán a technológiai paradigmák fogalmát E. Constant II., illetve Giovanni Dosi fejlesztették ki és alkalmazták munkáikban. Szemben Constanttal, aki technikatörténész, a gazdasági folyamatok ilyen nézốpontú vizsgálatában fóleg az utóbbi volt úttörố 1982-tól.

${ }^{4}$ Koevolúcióról a biológiában akkor beszélnek, ha két létezố egymás létezésének kölcsönös feltételévé válik anélkül, hogy közös génkészletük lenne. Általánosabb értelemben akkor is koevolúcióról beszélhetünk, ha két, egymástól eredetileg függetlenül változó rendszer kölcsönösen egymás feltételévé válik, s ezért kölcsönösen megjelennek egymás meghatározásában. Analogikusan értve, a múszaki fejlôdésben például egy elektromos és egy mechanikai rendszer egymás továbbfejlesztésének kölcsönös feltétele lehet.
} 
szó, hogy az innováció dinamikája paradigmaváltozás jellegủ, azaz a hosszabb, adott múszaki, technológiai paradigmán belül mozgó, normális, kis innovációk felhalmozásából álló szakaszokat pontszerúen megjelenố paradigmaváltások jellemzik? Attól függ. Szerintem a globalizálódó világban az innováció dinamikájában két irányban is alapvetô stratégiai változás megy végbe. Az egyik az, amit talán „radikális kis innovációknak” nevezhetünk egy elágazó innovációs láncban. Ez különösen a szolgáltatások világában demonstrálható könnyen. Elég hozzá a mobiltelefon által megvalósított szolgáltatások diverzifikálódását és rendszerjellegúvé válását követni az elmúlt kb. 15 évben, ahogy különbözô vállalatok más-más szolgáltatásokkal párosítottak régebbieket, kombinációval létrehozva 'radikális kis innovációkat'.

Másrészt egyre inkább megéri gazdaságilag, és ezt tekinthetjük az „új gazdaság” egyik indikátorának, ha adott innováció hosszú kiaknázási folyamata (a paradigma kimerítése) helyett már lehetóleg 'korán', adott irányú kiaknázási folyamat 'látható' kimerülése elốtt megpróbálkoznak lényegesen más innovációval az adott területen. A globalizált világban a körülményeknek akár kis megváltozása is lényeges esélyt adhat arra, hogy az eltérố alapokon létrehozott innováció mutáns gyorsan kiszorítsa elódjét, noha az még nem merült ki. Az ún. „új gazdaság” önszervezôdése és kialakuló sémái az innovációt ebbe az irányba is terelik. ${ }^{6}$ Ezért a globalizációval együtt járó másik alapvetố változás a radikális innovációk gyakoriságának megváltozása. Azt mondhatjuk, hogy az „új gazdaságban” a radikális innováció sokkal gyakoribb, mint a tömegtermelésen alapuló „régi gazdaságban”, és jellemzô a szinte állandó lehetôségében való bizakodás. Ezt a gyakoriságnövekedést általában a tudomány megnövekedett hatásának tulajdonítják.

Gyakran írják a versenyképességról, innovációról, műszaki fejlődésról szóló könyvek, hogy a nagy innovációk előzetes tudományos felfedezésen alapulnak. Ezt a megfigyelést azonban helyesbíteni kell. Alapvetô tudományos eredmények, például a nukleáris energia megismerése vagy a genetikus kód megfejtése általános, korszakot jelentố háttérváltozást képeznek egy-egy új innovációs korszak számára, s ezzel irányt szabnak, ebben van a döntő jelentőségük. Maguknak a nagy innovációknak és az alaptudományoknak az összefüggése konkrét esetekben azonban bonyolultabb. Például olyan korszakos innováció, mint a tranzisztor létrehozása, nem alaptudományi, szilárdtest-fizikai eredmény alkalmazása volt, hanem mérnöki, empirikus teljesítmény. A múszaki objektumok persze összetettek, sokféle irányban fejleszthetốk, akár egyidejúleg is, fóleg, ha ugyanazt a múszaki objektumot több, egymástól független helyen fejlesztik egyszerre. Így a tömegtermelésre jellemző lineáris paradigmadinamika mellett sor kerül az elágazó innovációs dinamika érvényesülésére is. Részletesen kidolgozott, jó példa erre a kerék-

\footnotetext{
${ }^{5}$ A másik példa lehetne a jégszekrény számítógépesítése, ami mára oda is elvezet, hogy előfordul, hogy a jégszekrény monitorát kommunikációs eszköznek is használják. Ennek megfelelôen billentyûzetet tesznek rá, internetezésre, rádiózásra, tévézésre is használják, mikrofonnal, minikamerával látják el, a családtagok üzenetet hagynak egymásnak stb., miközben, ne felejtsük el az eredeti funkciót, a jégszekrény hidegen tartja az élelmiszert.

${ }^{6} \mathrm{Az}$ „új gazdaság” terminust óvatosan, csupán mintegy jelzésszerú metaforaként használom. Közismert, hogy első alkalmazása problémákhoz vezetett a múlt század végén, mert számos ténnyel került ellentmondásba. Szerintem ennek fóleg az az oka, hogy elsố változatában ez a közelítésmód túlzottan leegyszerûsített kapcsolatot feltételezett az információ, a tudás és a gazdaság között.
} 
pár története a 19. század második felében. ${ }^{7}$ Ebben az esetben különbözó fejlesztók a kerékpár különbözô részeit egymás mellett, egyidejúleg fejlesztették, és a mutánsok, fejlesztôik révén, kölcsönhatásba léptek egymással.

\section{$2 \mathrm{Az}$ innováció neoklasszikus és evolucionista értelmezéséről}

Stilizált tényként ${ }^{8}$ az innovációról ma általában felsorolják annak interaktív, sokszorosan összetett, (lényegileg) bizonytalan és kumulatív (sémakövetố) jellegét. ${ }^{9}$ Másképpen megfogalmazva, az innováció egyszerre sémakövető és erősen kontextusfüggô, egyszóval útfüggő és útváltoztató jelenség. Ebból következik, hogy egyrészt nem lehet az innovációra szabványosított, univerzális jellemzést adni, amit csak alkalmazni kell majd az egyes esetekre, hanem a (radikális) innovációt a sémakövetés és a kontextusfüggés felbonthatatlan egységének kell tekinteni. ${ }^{10}$ Másrészt a (radikális) innovációtól

${ }^{7}$ A kerékpár ebben a korszakban végbement fejlődésének elágazó jellegére elsősorban W. Bijker és Tr. Pinch úttörố munkái kapcsán lehet rámutatni, noha ezeknek az esettanulmányoknak nem ez, hanem a kerékpár evolúciójának, a variációtermelés és a szelekciós folyamat kölcsönös dinamikájának bemutatása volt a célja.

${ }^{8}$ Stilizált tényekról akkor beszélnek, ha valamilyen univerzalizálható tapasztalatra utalnak. Stilizált ténynek tekintik, ha például azt állítják, hogy „valamely foglalkozás képviselói rájuk jellemzố módon viselkednek”, vagy ha azt mondják, „a fogyasztó általában megnézi, hogy mit vesz meg”, ha azt mondják, hogy „az eltérố viselkedések általában kiátlagolják egymást” stb. A „tény” jellegre való utalás az állítás robusztusságát, vitathatatlanságának mértékét fejezi ki. A stilizált jegyek segítségével megalkotható valamely adott struktúra vagy aktor általános érvényességúnek tekintett modellje

${ }^{9}$ Ezt a kumulatív, sémakövetổ jelleget modelleztem elóbb azzal, hogy a múszaki innovációt Dosi technológiai paradigmamodellje alapján részben normális szakaszú dinamikával jellemeztem. A normális szakaszban az innovációk adott irányban való felhalmozódása megy végbe, sémakövetô dinamikában, amit „forradalom" vált fel. Tapasztalati alapon már nagyon sok következik, sejthető ezekból az említett stilizált jegyekból. Az interaktivitásból például az, hogy nem várjuk el, hogy az innováció tipikusan lineáris legyen, hanem arra számítunk, hogy visszacsatolások és visszafordulások, újrakezdések jellemezzék. Következik az is, hogy ha valóban sikerre törekszünk, a stakeholdereknek helyet kell adni az innováció minden folyamatában, $s$ nem lehet egy-egy analitikusan megkülönböztetett fázist egy-egy tipikus ágenshez kötni, például azt várva, hogy a tudós kikutatja az alapinformációt stb., hanem keresni kell az adekvát interakciót a teljes innovációs folyamat minden szereplôje között. Ennek az interakciónak egyik izgalmas területe ma a legfejlettebb országokban a „felhasználók bevonása", ami a legfejlettebb formájában a lehetséges felhasználókkal együtt megvalósított, „együtt tervezett" innovációt tesz lehetővé.

${ }^{10}$ Ezzel magyarázható az a széles körü tapasztalat, ảmit az ún. ágazati innovációs paradoxon fejez ki stilizált tényként. E paradoxon szerint valamely ágazatban beváló (radikális) innovációmenedzselési módszerek egy másikban látványosan kudarcot vallhatnak. Ennek oka az, hogy a tipizálás az innováció feltételrendszerét képezố, rendszerint sokdimenziós rendszer viszonyai között inherens feszültségben van a lényegi kontextusfüggéssel: más-más tényezók és azok kölcsönhatásai válhatnak döntôvé még látszólag egymáshoz közeli esetekben is. A lényegi kontextusfüggés nemcsak azért nehezíti meg az általánosítást, mert sok paraméter kölcsönhatásáról van szó, hanem azért is, mert intenzív kölcsönhatási viszonyok között „lényegi bizonytalanság” uralkodik. Radikális innováció esetében az erôs kontextusfüggés miatt nem lehet a lehetséges kimenetet jól ismerni, ezért hiányzik a „legjobb gyakorlat” megállapíthatóságának egyik elengedhetetlen feltétele. Általánosítható tapasztalatként inkább az ajánlható a képzés számára, hogy hasznos módszerként készséget kell kifejleszteni a metaszintú elemzésre, a keretreflektív gondolkodásra, és ezt sok „rejtett” (tacit) ismeret megszerzésével mindenekelött a gyakorlatban kell elsajátíttatni. 
áthatott világ pontszerú egyensúlyváltásokon megy keresztül. A globalizáció körülményei között intenzív kölcsönhatásokat mutató világrendszerben a tudás, a kompetencia és az innováció központi tényezővé válik a gazdaság számára, amiról elengedhetetlen tudományosan számot adni. Talán érdemes kiemelni, hogy a gazdaságtudomány egyre adekvátabban számol be arról, hogy a globalizáció körülményei között a gazdaság dinamikája nem tekinthetô erôsen autonómnak, és nem is csupán „beágyazott”, ahogy erre a gazdaság társadalmi viszonyaival foglalkozó szociológia már régen rámutatott, hanem minden társadalmi viszony gazdasági tényezôvé válik. Az ilyen rendszerdinamika adekvát vizsgálata a korábban megszokott gazdaságtudományi szemléletmódok komplex rendszerdinamikai és evolúciós szemlélet szerinti megújítását követeli meg. Ezzel együtt a tudomány feladatává válik, hogy kidolgozza a módját annak, hogy minden társadalmi viszonyról mint gazdasági tényezóról számot adjon.

Az utóbbi 50-60 évben viszont az innováció neoklasszikus közgazdaságtani megközelítése volt jellemzô. Mint ismeretes, a neoklasszikus közgazdaságtan központi témáját a gazdasági egyensúly és az egyensúlyból való kimozdítás után az egyensúlyhoz való visszatérés megmagyarázása adja. Azt mondhatjuk, hogy neoklasszikus módon olyan innovációkról lehet érvényesen beszámolni, amelyek eléggé kis innovációk, ezért nem követelik meg a neoklasszikus alapfeltevések gyökeres kicserélését. Kritikusai megállapítják, hogy az innováció neoklasszikus jellemzése azzal kapott némi valószerúséget, magyarázó erốt, hogy az innováció régebben marginális, vagy legalábbis sokkal marginálisabb jelenség volt, mint ma, amikor a gazdaság (és a társadalom) központi jelenségévé válik. Alapfeltevései miatt az innováció neoklasszikus gazdaságtani felfogása ebben az új helyzetben alapvetốen félrevezetố lesz. ${ }^{11}$ Hasznos ezért összefoglalni, miért inadekvát a neoklasszikus felfogás, ha az innováció a globalizáció körülményei között valósul meg, és hasznos szembeállítani kiindulópontjait az innováció adekvátabb nézetének mutatkozó evolucionista nézet kiindulópontjaival. Anélkül, hogy kimerítô lista felállítására törekednék, az alábbiakban felsorolok számos tipikus jellemzốt.

A neoklasszikus felfogás szerint:

1. A gazdaság szereplő́i optimalizáló magatartást tanúsítanak (az optimalizáló tervezó modellje).

2. A gazdasági rendszerben végbemenő folyamatok önmaguktól egyensúly felé mozognak. (A rekonstrukció és a magyarázat kiinduló ontológiai feltevése az önmagában levố rendszer és folyamat.) Ebból az egyensúlyból a rendszert külsó hatások mozdítják ki.

3. A szereplők azonos tudással, kompetenciával rendelkeznek. A szereplóket, például a vállalatokat helyettesíthetjük a reprezentatív szereplóvel, reprezentatív vállalattal. A neoklasszikus gondolkodás tipikus cselekvókkel számol, mert egyensúlyi helyzeteket vizsgál, illetve azért, mert így leegyszerúsítheti a számítást.

${ }^{11}$ Például Lundwall és Boras nagyon élesen fogalmazza meg azt, ami az innovációval elméleti szinten is foglalkozók számára egyre inkább általánosan elfogadott értékelés: a neoklasszikus elmélet feltevései inkompatibilisak azzal a dinamikus gazdasággal, amelyben az innováció elterjedt és állandóan végbemegy (Lundwall, Boras, 2004). 
4. A tudás lényegében kodifikált információ. ${ }^{12}$ A nem kodifikált tudás csak kiegészítő jelentôségú, lokális feltételek ismeretét jelenti, és a know-how terén megnyilvánuló ügyességben (skills) nyilvánul meg.

5. A bizonytalanság kiszámítható.

6. Jellemzố ebben a gondolkodásmódban az a feltevés, hogy a vizsgált gazdasági dinamikához való alkalmazkodás elsőfokú tanulással, az információszerzés és kodifikálás módjainak megtanulásával elégségesen biztosítható. A csak a gyakorlatban megszerezhețố ügyesség a lokális feltételek megismerésére korlátozódik, az információrendszerek mint egészek reflektív vizsgálatára pedig csak nagyon ritkán van szükség.

7. Az innováció folyamata a feltalálástól a megvalósítás felé vezetô, alapvetően egyirányú és lineáris folyamat.

8. Az innováció egyszerú rendszerben megy végbe: az innovációs folyamat nem optimális múködésének alapvetố oka az, hogy a neoklasszikus módon felfogott gazdasági rendszerben szükségképpen nem történik elegendő beruházás az innovációba, amit a neoklasszikus előfeltevések kielégítően megmagyaráznak. ${ }^{13}$ A rendszer egyszerú abban az értelemben, hogy ez okozza az alapvetô problémát.

9. A gazdasági rendszer múködésének e szükségszerú hibája miatt az innováció optimalizálása allokációs jellegú köztámogatást követel meg. Ugyanakkor a rendszerviselkedés optimuma - elvileg - kiszámítható. Ezért lehetséges a hibás piaci szabályozás állami korrekciója, ami éppen ezen optimum megközelítésére irányul. A piac és az állam együtt elvileg teljes korrekcióra képes szabályozást valósít meg. ${ }^{14}$ A köz, a politika szerepe az, hogy a piaci „logika” hibáját kijavítsa, azaz kompenzálja a piaci kudarcot és alulberuházást. E mögött az a nézet van, hogy a politika képes erre. A gyakorlatban viszont tudjuk, hogy a tényleges politikai „logikának” inherens hibái vannak, például a választási ciklusokhoz kötött stb. Ugyanakkor ennél is jelentôsebb, hogy az evolucionista felfogás szerint az állami tervező optimalizáló modellje a megtervezendő rendszer evolúciós természete miatt nem valósítható meg.

10. Mivel a korrigált allokáció közvetlen kiválasztáson nyugszik, azaz a legjobbnak (legjobbként azonosítottnak) nyújt támogatást, pontosabban ezzel teszi megvalósíthatóvá, hogy a támogatott a legjobbnak bizonyuljon, a (neoklasszikus módon múködó) piac és az allokációs feladatot ellátó állam együttesen - elméletileg ideáltipikusan - megvalósítja a lehetséges legjobb rendszert.

11. Az „innovációs lánc” szakpolitikai kezelésére három elkülöníthető, egymáshoz csak kívülról kapcsolódó szakpolitika, a tudomány-, a technika- és az innovációpolitika együttes felhasználása szolgál.

\footnotetext{
${ }^{12}$ A kodifikált tudás legfejlettebb formájában matematikailag kifejezett tudás.

${ }^{13} \mathrm{Ez}$ azt jelenti, hogy az adott gazdasági rendszerben optimálisan megvalósítható innovációhoz képest a rendszer spontán múködése esetén a rendszer múködési törvényei miatt szükségszerúen kisebb mértékú innováció jön létre.

${ }^{14}$ Ugyanakkor érvényes az az elv is, hogy a neoklasszikusan feltételezett piacgazdasági körülmények között az innovációs láncba történő allokációs beavatkozás annál indokoltabb, minél közelebb vagyunk az alaptudományokhoz.
} 
12. A jövóhöz való viszony trendek uralmának feltételezésén alapszik, amihez az informált cselekvố lényegében csak alkalmazkodik. A jövókutatás trendelemzésen alapszik.

13. Lehetséges kvantitatív valószínúségszámításra alapozott lineáris, visszacsatolás jellegû́ tervezés, ami a kitűzött cél iteratív megközelítését valósítja meg.

14. A fentiek alapján összefoglalóan elmondható, hogy a feltételezett dinamika mindenképpen statikus jelleget ốriz meg, ami csak átrendezôdést és növekedést tesz lehetôvé.

Az evolucionista gazdaságtan szerint viszont:

1. Az innováció interaktív folyamatban megy végbe, amelyben

2. a cselekvốk egyedi helyzetük miatt szükségszerúen különböznek, például tudásban, kompetenciában és racionalitásban, a más forrásokhoz való hozzáférés képességében, tanulási képességükben stb.

3. A cselekvốk különbözôsége döntố lesz mind az innováció inicializálásában és megvalósításában, mind pedig abban, hogy követni legyenek képesek a megvalósult innovációt, azaz a valós szereplók semmilyen érvényesnek tekinthetố absztrakcióban nem helyettesíthetók a reprezentatív szereplővel. Az alapvetó aktoregység nem az egyedi szereplő, hanem a populáció. A valós szereplók interaktív folyamatokban léteznek, eltérố kompetenciákkal, racionalitással és tanulási képességgel, és nem független individuumok, hanem különböző viszonyrendszerekbe beágyazott, lokálisan különböző, sokszor hálózati szereplók. (Ezen egyedi szereplók adekvát leírása nem lehetséges viszonyrendszereiktól függetlenül, egyediségük éppen sajátos viszonyrendszerükkel összefüggésben nyilvánul meg.)

4. Alapvetôen fontos, hogy a vizsgált rendszer dinamikája sokszor eltávolodik az egyensúlyi helyzettól. Ebben a dinamikában döntố jelentôségű az, hogy a rendszerben szükségszerúen vannak az átlagtól szélsôségesen is eltérôen viselkedő́ágensek. Bizonyos viselkedésük nem átlagolódik ki, és ezért új egyensúlyi állapot kialakulásánál alapvetô jelentôségük lesz. Ezek a potenciális innovátorok, akik, megfelelố rendszer-dinamikai állapot mellett, hozzájárulnak az új út létrehozásához, a rendszerdinamika által megengedett alternatívamezôn belül. Az innováció folyamata során az ágensek tipikusan átalakulnak, akár ki is szelektálódnak.

5. A változás ritkán vezet egyensúlyhoz, a tipikus dinamika alapvetôen pozitív vagy negatív elójelú önmegerôsítô körök létrejöttét eredményezi. Ennek következtében a távolságok a rendszer szereplói között tipikusan nóhetnek, hosszú távon is, különösen akkor, ha innovatív történeti szakaszok hézagtalanul követik egymást.

6. Az innováció variációs és szelekciós folyamatok kölcsönhatásában megy végbe.

7. Az innováció során a bizonytalanság az alapvetô, nem a kiszámítható kockázat. ${ }^{15}$

\footnotetext{
${ }^{15}$ Mint közismert, Kenneth Arrow egyike volt az elsóknek a 70-es évek elején, akik rámutattak az innováció ilyen jellegére, pontosabban arra, hogy a (radikális) innováció definíciószerúen tartalmaz fundamentális bizonytalanságot.
} 
8. Az innováció komplex, nyitott folyamatban megy végbe, amelyben a piaci kudarc és az alulberuházás mellett a kudarcok sokfélesége jellemzô. Ugyanakkor az innovációs folyamat tipikusan sokáig maga is par excellence piaci kudarcnak tekinthetô. $^{16}$

Röviden utalok az irodalom alapján az innovációt kísérố kudarcok sokféleségére. Ilyen lehet az, hogy az innovátor képtelen biztosítani vagy megszerezni az innováció megvalósulásához nélkülözhetetlen infrastruktúrát, vagy képtelen megvalósítani a szükséges átmenetet, elkerülni a „bezáródást”, megkapni a szükséges intézményi strukturális támogatást. Az innovációt különbözố „csapdák” kísérik. Ezek lehetnek például evolúciós csapdák, rossz útfüggés („,bezáródás”) kialakulása, tanulási kudarc, a „kiaknázás vagy kikutatás” dilemmájának rossz megközelítéséból adódó csapda, a variáció és a szelekció rossz viszonya, vagy a legkülönbözôbb olyan kompetenciák kiépítésére való képtelenség, amelyeknek az együttes megléte nélkül az innovációs próbálkozás kudarcot vall. Ezek általában változatos kombinációban lépnek fel. A legkevesebb, ami elmondható, az az, hogy a széles megközelítésú, rendszerszemléleten nyugvó evolúciós gondolkodás komparatív elônnyel rendelkezik, amikor számot kell adni ezekról a kudarcokról és csapdákról.

9. Az innováció nem lineáris folyamat: elágazások, visszacsatolások, újrakezdések és hálószerú fejlődés jellemzik.

10. A 'valódi piac' részben szervezett jellegú, s ezzel keretet biztosít az interaktív tanulásra, hiszen ez a tanulás a 'valódi piac' szerveződésének integratív része. A piac szerveződésének részeként sokszereplôs, sokdimenziós interaktív tanulási folyamat valósul meg, ami visszacsatoló szabályozóelemként múködik. Ennek egyik esete a ma lassan „divatossá” váló szervezett interaktív tanulási folyamat a termelố és a felhasználó között. Ez a már említett radikális bizonytalanság csökkentésére, bizonyos fajta „eredeti meglepetések” elkerülésére és egyben a kreatív munkába bevontak körének kiszélesítésére szolgál. ${ }^{17}$

11. Az innováció során hasznosuló tudás mind kodifikált, mind tacit vagy „rejtett” jellegú. Ez a „rejtett” tudás „néma”, vagyis „ügyességben” (skill) megnyilvánuló, illetve „szótlan” is lehet, tipikus esetben mind a kettô. ${ }^{18}$ Ha radikális innováció kifejlesztése a tét, akkor a tanulás és a tanulóképesség nem információszerzésként és kodifikációként döntô jelentôségú az innovatív rendszerekben, hanem mint keretreflektív tanulás, illetve ügyesség (skill) és képesség. ${ }^{19}$ Ilyenkor a keretreflektív tanulás és az ügyesség kombinációjára van

\footnotetext{
${ }^{16}$ Kifejlesztése során az innováció általában sokáig vissza nem térülő beruházás, ami bizonyos szempontból „csak viszi a pénzt”.

${ }^{17}$ Fontos észrevenni a párhuzamosságot a felhasználónak, a fogyasztónak a bevonásában a piacon, illetve a közigazgatás mint szolgáltató által produkált termékek fogyasztása esetén. Erról részletesebben írtam egy korábbi tanulmányban (Hronszky, 2005b).

${ }^{18}$ „Néma”, rejtett tudás lehet olyan fizikai ügyesség, mint az úszni vagy kerékpározni tudás, de lehet példamegoldási ügyesség is. „Szótlannak” a közös, de explicit hivatkozást nem igénylő, ki nem mondott tudást tekintik, ami a kommunikáció alapjául szolgál.

${ }^{19}$ Ezzel nem akarjuk kétségbe vonni az információszerzés és -kodifikáció jelentôségét, hanem azt állítjuk, hogy mellette megváltozik a keretreflektív tanulás és az ügyesség jelentősége.
} 
szükség. Sajnos a jelenlegi egyetemi képzés a maga prelegáló stílusával és a tanteremben előadottak laboratóriumi gyakoroltatásával ezt inkább akadályozza, mintsem elôsegíti. ${ }^{20}$

12. A politika nem képes arra, hogy korrigálja az optimumhoz képest fellépó hibát. A szakpolitika allokációs törekvése legfeljebb rövid távon és nem erôsen turbulens közegben eredményez sikert. Ugyanis vagy nem lehet ilyen optimumot kiszámítani valós helyzetekre már viszonylag egyszerú esetekben sem (erre számos elméleti közgazdász mutatott példákat), vagy az elengedhetetlen elhanyagolások miatt a számítások nyilvánvalóan nem valószerúek, és még ennél is fontosabb, hogy az innovációs rendszerek nem lineáris természete eleve megkérdôjelezi az ilyen optimumszámításokat. Ezért az evolucionista gondolkodás szellemében kénytelenek vagyunk feladni a politikai tervezố mint korrektor célkitúzését. Ezzel szemben a politika viszont meg tud valósítani egy másik feladatot, a koordinációt, s ezzel elố tudja segíteni az evolúciót moduláló beavatkozás megvalósulását mint adaptív alkalmazkodást. Belátható, hogy ezzel a piacot valóban hatékonyan tudja kiegészíteni, mivel a teljes szabályozási folyamathoz hozzáad egy csak rá jellemző elemet.

A korszerú szakpolitika nem önállóan kifejlesztett részpolitikák összekapcsolása, hanem a korábbi tudomány-, technika- és innovációpolitika átfogó egysége. Ennek a szakpolitikának integratív módon kell beépülnie további más szakpolitikákba, például a képzés politikájába, mégpedig valamennyit horizontálisan áthatóan. Mint definíciója része, nemcsak ezzel az integráló, holisztikus struktúrával különbözik a neoklasszikus alapon létrehozott politikától, hanem részben más alapvetố feladatokkal rendelkezik, mint a neoklasszikus módon felfogott tudomány-, technika- és innovációpolitika együttese. Ez az innovációpolitika alapvetóen kettős koordináló feladatot lát el: egyrészt hozzájárul ahhoz, hogy a piac spontán múködésével és a versenypolitikával a lehetố legélesebbé tett versenyfeltételek között jó innovációs válasz jöjjön létre, mivel biztosítja az innovációs verseny háttérfeltétel-rendszerét, másrészt ott, ahol szükségesnek mutatkozik, a győzelemre vagy legalábbis akkomodációra esélyes versengók ideiglenes támogatásával segít a szúk keresztmetszetet képezô problémák áthidalásában. ${ }^{21}$ Ennek a kettôs koordináló feladatnak az ellátásával a szakpolitika kihasználja mindazt, aminek birtokában a szükségszerúen bizonytalan tudású közegben minden más szereplôvel szemben komparatív elốnnyel rendelkezik.

13. A jövóhöz való viszony elốrelátás (foresight) jellegú, nem trendvonalak felállításában és elemzésében merül ki, hanem kombinálja a trendelemzést és a

${ }^{20} 2001$ és 2003 között részt vettem az Európai Bizottság Kutatási Fốigazgatóságának egyik HLE (magas szintứ) szakértối csoportjának munkájában, amelyik annak az elốrejelzésével foglalkozott, hogy a kutatás és az egyetemi képzés módja hogyan fog megváltozni. A csoport munkájához készített kéziratos anyag alapján több tanulmányban foglalkoztam ezzel a kérdéssel (lásd például Hronszky, 2006a, 2006b).

${ }^{21}$ Amennyiben evolucionista értelmezésben (vagyis a szúk keresztmetszetet képezô problémák áthidalása érdekében a feltételrendszert modifikáló törekvéssel, illetve direkt beavatkozással) kerül sor szakpolitikai beavatkozásra, akkor nem érvényes az a tétel, hogy az innovációpolitika annál kevésbé avatkozik közbe, minél közelebb vagyunk az innováció piaci megvalósításához. Kiemelkedố jelentôségũ lehet például a találmány piacra vitelének elốsegítése. 
szcenáriómódszert, elfogadva, hogy a jövố egyformán alapvetố szinten determinált és indeterminált.

14. Radikális innováció koevolúcióval, a koevolúció modifikálását jelentő új utak létrehozásával jön létre. Ez azt jelenti, hogy az evolúciós szemlélet a szereplók intencionalitásából kiindulva kimutatja azok lehetôségeit a kialakuló sémák, „utak” megváltoztatására bizonyos kedvezó körülmények, bifurkációs pontok elérése esetén. Így a lineáris visszacsatolt tervezés helyére, ami csak az adott cél egyre jobb megközelítésére alkalmas, a dinamikus tervezés lép, ami lehetôvé teszi, hogy racionalitás jusson érvényre akkor is, amikor mind a szereplók, mind a feltételrendszerek változnak és kölcsönösen módosítják egymást.

Mindezek alapján megállapíthatjuk, hogy alapvetô ontológiai és episztemológiai szembenállás van az innováció neoklasszikus és evolucionista felfogása között: másfajta létezók más-más dinamikával mozognak az egyik vagy a másik modellben, s eltérô a megismerés lehetségesnek gondolt módja is. Más-más világokat definiálnak, s ez alapvetően eltérô pragmatikához, szakpolitikához és innovációmenedzsmenthez vezet.

Szeretnék mellékesen egy megjegyzést tenni, ami azonban elég fontos lehet annak a tárgynak az elterjedt és makacs félreértése miatt, amelye vonatkozik. Szokásos azt mondani, hogy a neoklasszikus felfogásról az evolúciósra való áttérés lényege a mechanikai analógiáról (mechanikai „gyökérmetaforáról”) a biológiai analógiára (biológiai "gyökérmetaforára") való áttérésben van. ${ }^{22}$ Helyesebb, de még mindig alapvetôen félrevezető a mechanikai analógia helyett newtoni szemléletet mondani, s ezt szembeállítani a biológiaival. A lényeg ugyanis a lineáris rendszerekben gondolkodásról a komplex rendszerek dinamikája szemléletmódra való áttérésben van. Ez pedig akár már mechanikai problémáknál is jelentkezhet. Peter Allent, a fizikusként már a 80 -as években közgazdasági problémákkal foglalkozó kutatót idézve foglaljuk össze, miben áll a két felfogás alapvetô ellentéte. Allen már ekkor világosan rámutatott arra, hogy az egyensúlyi viselkedés jó leírására koncentráló metodika helyett, ami az egyensúlyitól távoli rendszerekre áttérve leírta az átlagos viselkedéssel (és az egymást kiátlagoló eltérésekkel) jellemezhetố mechanizmust, vissza kell vinni, amit elvettünk a rendszer viselkedésének koncepciójából: „A 'modell' vagy 'redukált leírás' mögött azonban mindig a valóság nagyobb partikularitása és változatossága van. A valódi rendszerek fejlődnek, azaz idővel hozzáadnak és helyettesítenek mechanizmusokat, komponenseket és kölcsönhatásokat, míg a determinisztikus modellek nem teszik meg ezt. Az evolúciós változásnak tehát abból kell származnia, ami az átlagossal való leírással elvégzett redukcióval 'el lett távolítva' a teljes rendszerból. A determinizmust a strukturális változás árán vették meg.” Allen így folytatja: „Kimutattam, hogy amikor újra bevezetik a nem átlagos perturbációkat, akkor 'evolúciós hajtóerố jelenik meg, ami inkább szelektál olyan populációk javára, amelyeknek képességük van a tanulásra, mint amelyeknek optimális a viselkedése. Ez megfelel az 'eltéréseket létrehozó' mechanizmusoknak a populációk viselkedésében. A modellekben, amelyeket kifejlesztettem, a rendszer ténylegesen előforduló evolúciós útja a történet véletlenségeitôl, valamint a kontextuális és nem át-

${ }^{22}$ A „gyökérmetafora” nyújtja valamely terület értelmezésének alapját, számot adva azokról a létezókról, amelyekkel a megismerố benépesíti az adott területet. 
lagos részletektól függ. Az ilyen rendszer jövôje kétfajta terminustól függ: az átlagos komponenseinek tipikus viselkedése következtében fellépő determinisztikus akcióktól és azoktól a strukturális minôségi változásoktól, amelyek a rendszer nem átlagos összetevőitól és feltételeitól függnek. Dialógust találunk a választott leírás 'átlagon alapuló dinamikája' és a körülötte megjelenő, kikutató jellegú, előre láthatatlan perturbációk között, ami a nem átlagos események és összetevók elkerülhetetlen elófordulásából ered." 23

Tiltakoztam az ellen, hogy a neoklasszikus gondolkodást meghatározó determinista világképról az evolúciós gondolkodásra való áttérést leegyszerúsítsék arra, hogy a mechanikai analógiákról biológiai analógiákra térnek át, mivel nemcsak biológiai analógiákról, hanem az egyensúlytól távoli viselkedést is mutató komplex dinamikus rendszerek viselkedésére vonatkozó tudás felhasználásáról is szó van, tehát a megalapozó analógia-rendszer („gyökérmetafora”) összetettebb, és a komplex rendszerdinamika mint szemlélet érvényesíthetônek bizonyul már az élettelen természet folyamataira is. Ezzel lehetôvé válik, hogy átfogóan szemléljünk minden folyamatot, a szervetlen természettól a társadalmi folyamatokig. Ez a konzekvens kiindulópont természetesen egyáltalán nem jelenti azt, hogy létezne már az innováció evolúciós elmélete, noha a kutatás bizonyosan túl van azon, hogy csak alkalmi analógiák keresése lenne, miközben az analógiák kihasználási metodikájának következményeként a biológiai analógiák érvényesítése a gazdasági folyamatok értelmezésében maga is elkerülhetetlen tanulási folyamat, ami csak szükségszerú tévedéseken, az analógiák „túlfeszítésén” keresztül valósulhat meg.

\section{Néhány szó a bizonytalanságról}

Az alapvetố innovációk egyik döntô jellemzóje mind céljaik, mind a hozzájuk vezetố út alapvetố bizonytalansága. Az irodalom alapján stilizált tényként elfogadottnak tekinthetjük, hogy a nagy, áttörố innovációkat átfogó alapvetố bizonytalanság, „tudatlanság” jellemzi. Mit értünk alapvetố bizonytalanságon, „tudatlanságon”? Ezt legegyszerúbben a kvantitatív kockázatszámításhoz szükséges alapfeltételek teljesülésének vagy nemteljesülésének vizsgálatából kiindulva vezethetjük be. A kvantitatív kockázatszámításhoz a vizsgált jelenségek diszjunkt halmazának és a jelenségek előfordulási valószínúségeinek előzetes ismeretére van szükség. Feltételezhetjük, hogy a jelenségeket és előfordulási valószínúségeiket egyes folyamatokban kevésbé ismerjük, mint másokban. Ezért a jelenségek és elófordulási valószínúségeik ismeretére vonatkozó bizonyos tartományban megjelenik az, amit „,eredeti meglepetésnek” (genuine surprise) nevezünk, ami a bizonytalanság, a „tudatlanság” tartománya. ${ }^{24}$ Belátható, hogy legalábbis a lényeges, nagy innovációkra jellemzố az „eredeti meglepetés”.

${ }^{23}$ Allen, Peter, 1993. Allen visszafelé is alkalmazza az evolúciós metaforát, sốt az innovátor metaforáját is. Így bizonyos perturbációk a rendszerben lehetséges állapotváltozások „,kikutatóinak” mutatkoznak, a deviáns aktorok pedig innovátorok

${ }^{24} \mathrm{Ez}$ az a terület, amire az óvatossági elv (precautionary principle) lehet érvényes mint a menedzsment alapvetố racionális magatartása. Ez az elv mindenekeloótt a környezetvédelem, illetve a meglevô rendszer megốrzésének igénye kapcsán merül fel és válik szükségszerúvé. Az innováció számára a racionális vezérlőelv 


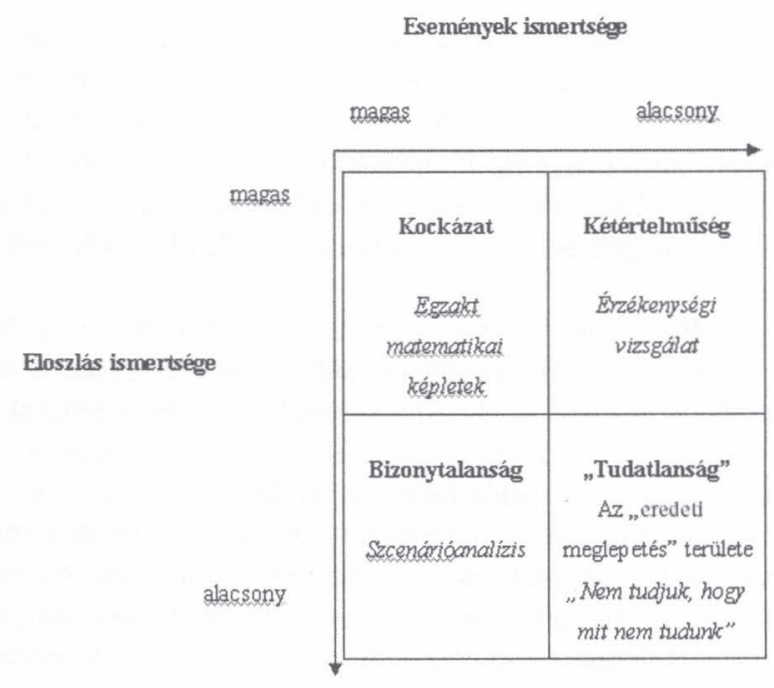

(A szükséges paraméterekról, eseményekról és gyakoriságukról való tudás bizonyossága az ábra tengelyein balról jobbra és fentról lefelé csökken. ${ }^{25}$

Fontos észrevennünk, hogy kétféle bizonytalanság jellemzi az innovációs folyamatokat, ha azok nagy, áttörố innovációra irányulnak. Az egyik az elóbb említett információs bizonytalanság, amely elkerülhetetlen jellemzóje minden innovációs folyamatnak, még akkor is, ha tudományos problémának tekintve az innovációs problémát, azt mondanánk, hogy nincs elvi akadálya a „teljes” információszerzésnek. Az innovációs folyamatokban azonban döntéskényszerekról és az adott idő alatt beszerezhetô információról van szó, ezért bizonyos bizonytalanság akkor is kiküszöbölhetetlen, ha elegendő idố esetén a tudományos kutatás kiküszöbölhetné. A másik bizonytalanság viszont rendszer-dinamikai jellegú: a rendszerek nem lineáris természetében rejlik. A bizonytalanság menedzselésének problémáját csak tovább nehezíti, hogy a „kockázati tájkép” (risk landscape) az innovációban sokdimenziós, azaz nagyon sok paraméterre vonatkozhat, és struktúrája, kontúrjai és dinamikája alapvetően bizonytalanok, miközben fennáll a rendelkezésre álló idő alatt való „eltájékozódás” követelménye. Ezért szokták hangsúlyozni az irodalomban, hogy a radikális innováció megvalósítása inherensen kísérletezô folyamat: bizonyos szakaszokban bele kell vágni, miközben igyekezni kell megfelelöen tanulni.

keresésének problémája radikális innováció esetén éppen fordítva, a meglevố rendszer radikális megváltoztatására irányul. (A kockázati tóke racionális értelmezésében megjelenô plauzibilitást hangsúlyozó érvelés éppen a fordítottja az óvatossági elv racionális értelmezését megalapozó plauzibilitásra hivatkozó érvelésnek.) A környezetileg és társadalmilag elfogadható és fenntartható innováció racionális elvének keresése ezért inherensen ellentmondásos. Ebben a tanulmányban csak jelezni tudom ezt az ellentmondást, pedig ebben és praktikus megoldásaiban súrítve van a környezetileg és társadalmilag egyaránt elfogadható, fenntartható innováció alapvetố problémája.

${ }^{25}$ Az ábra forrása: Stirling, 1999, 26. 


\section{$2 /$ Áttörő innovációk társadalmilag fenntartható menedzselése}

Átfogó evolucionista közgazdasági elmélet hiányában úgy tûnhet, hogy az evolucionista szemléletmód elsôsorban még csupán a saját megalapozásával bajlódik. E félreértés eloszlatására szeretnék néhány szót mondani az áttörô innováció „társadalmilag robusztus" (társadalmilag fenntartható) menedzseléséról. ${ }^{26}$ Ez ugyanis a menedzsmentról evolucionista szemléletmódra alapozottan történó gondolkodás szépen kidolgozott példája. A „társadalmi robusztusság” azt fejezi ki, hogy mekkora az a népesség, melynek számára valamely adott javaslat elfogadható. A társadalmi fenntarthatóság alatt két dolgot szoktak érteni. Az egyik, hogy létrehozható-e olyan támogató rendszer az innováció számára, amely stabilizálja azt. A másik értelemben arról van szó, hogy az adott innováció környezetileg, egészségi szempontból stb. elfogadható-e. Az innovációtól ma már nemcsak olyan újdonságot várnak el a legfejlettebb országokban, ami a versenyképességben megjelenik, hanem a versenyképesség ideális esetben úgy szabályozódik (az állam és a fogyasztók együttmúködésével), hogy ami nem környezetbarát és társadalmilag (például az egészség vagy a kulturálisan beágyazódott szokások szempontjából) nem elfogadható, az nem is versenyképes, sốt esetleg ki is tiltják a piacról. Ezzel kapcsolatban utalni szeretnék néhány egyre gyorsabban elterjedő felismerésre. Az elsô az, hogy a fogyasztó (illetve a felhasználó) bevonása már a piacra kerülés elốtti szakaszban alapvetố eszközzé vált az ilyen eljárások és termékek elbírálásában. Ez a „bevonás”, az eljárások vagy a késztermékek hatásának az értékelésében való részvétel ma már számos esetben eléri az „,együtt tervezés” szintjét. ${ }^{27}$

Akár „,bevonás”, azaz az elkészült termék hatásainak vizsgálatában való részvétel, akár együttes tervezés eredményeként jön létre a termék, amikor a participáció már a célkitúzésben való részvételt is jelenti, nem csupán a hatások vizsgálatában való részvételt, az innovációnak jellemzóje lesz a társadalmi robusztussága, más kifejezéssel élve: a társadalmi beágyazottsága. Ez lényegében azt jelenti, hogy milyen különböző társadalmi rétegek és milyen mértékben fogadják el. Még egy vonatkozásra érdemes röviden kitérni. Valamivel több mint 30 éve jelentek meg az elsố kötelezó környezetvédelmi és technológiai hatáselemzési vizsgálatok az USÁ-ban. Ezek elốször a megvalósult technikák hatásainak vizsgálatát írták elő. Nyilvánvaló, hogy a továbblépés az volt, hogy az ilyen elóírásoknak megfelelő tervezối munka kötelezóen a technológiatervezés része legyen. Mára a visszacsatolás és az anticipáció egyaránt továbbfejlődött, és a nanotechnológiai alapú, ún. konvergens technológiai fejlődés esetében hangsúly kerül az un. „kétszeresen fiktív" feladatok ellátására is. ${ }^{28} \mathrm{Ez}$ annyit jelent, hogy az elképzelhetố

\footnotetext{
${ }^{26}$ Becslések szerint a vállalatoknál végrehajtott innovációs projekteknek kb. tizedrésze tartozik az áttörố innovációk közé. Ugyanakkor gazdasági jelentôségük ennél összehasonlíthatatlanul nagyobb.

${ }^{27} \mathrm{Ez}$ az „együtt tervezô” hozzáállással megcélzott, közrészvétellel folyó múszaki tervezés először Hollandiában és Dániában valósult meg, elsôsorban közberuházással végrehajtott múszaki beruházások negatív hatásainak elốzetes kiküszöbölése céljából. Ma már a közrészvétel kezd kiterjedni a múszaki tervezés céljának, illetve nagyobb mûszaki trendek társadalmi értelmének közös megvitatására is.

${ }^{28}$ A nanotechnológiát, lényegében az atomi-molekuláris szintnek ezt az új típusú tudományos és múszaki megközelítését korunk egyik legígéretesebb müszaki fejlődési lehetôségének tekinthetjük. A nanotechnológia eredményei alapvetô minôségi fejlődés lehetôségeit ígérik más területeknek is. Ezek viszont
} 
technológiák lehetséges társadalmi és környezeti hatásainak felbecsülése a sciencefiction körébe tartozó irodalmi múvek próbálkozásai mellett állami, illetve vállalati tervezési feladattá is vált, azzal a céllal, hogy a kutatás kezdetétól biztosítsák a legszélesebb társadalmi támogatottságot, a robusztusságot az egész folyamatban. ${ }^{29}$

Áttekintve a menedzsment irodalmát, jól láthatjuk, hogy kis innovációk menedzselésére jól kidolgozott és jól beváló eszközök és technikák állnak rendelkezésre. Ugyanakkor, ahogy a SOCROBUST-projekt résztvevói joggal állapították meg 2002ben: az a fó baj ezzel az arzenállal, hogy eloofeltételezi a múszaki, a szabályozási és a piaci környezet stabilitását. ${ }^{30}$ Azaz az innováció megvalósulásához szükséges és a megvalósult innovációval létrejövő változást elég kicsinek elófeltételezi, hogy a megszokott menedzselési módszerek átvihetók legyenek. Miután minden múszaki változás társadalmi változás is, azt mondhatjuk, hogy a kis innováció vagy változatlanul hagyja a társadalmi „környezetet” (például azért, mert már létezik fogyasztói igény iránta, mert nem kell a regulációs vagy a múszaki-gazdasági környezetet lényegesen módosítani), vagy csak kis változásokat kényszerít ki a megfelelő alkalmazkodáshoz (például megfelelő fogyasztói igény felkeltésével). Említettem már, hogy az irodalom alapján stilizált ténynek tekinthetjük, hogy a nagy, áttöroó innovációkat alapvetố bizonytalanság jellemzi. Érdemes ezt a bizonytalanságot per definitionem a nagy, áttörő innováció alapvető részének és egyben empirikus indikátorának tekinteni. Nézzük meg, milyen kényszereket hoz ez magával az áttörố innovációk menedzselése számára. Valamivel részletesebben a projektmenedzseléssel szembeni kihívásokra és az ajánlott megoldásra fogok kitérni.

Az irodalomban kb. a 90-es évek közepétól található meg az a felismerés, hogy radikális innovációknál eltérő menedzselésre, a nagy innovációra törekvő projektek vállalaton belüli sajátos pozicionálására van szükség. Ez új szervezeti, vezetố- és csapatkiválasztási, finanszírozási és módszerválasztási feladatokat is jelent. Amíg például a kis innovációk kockázatai érzékenységi analízissel segítve viszonylag jól kiszámíthatók, s ezért viszonylag pontos összehasonlításokon nyugodhat a vállalati szelekciós döntés, nagy innovációt megcélzó projekteknél a hagyományos számítási eljárások legfeljebb formálisan érvényesek. Az irodalmi javaslatok, amelyek nagyrészt kiválasztott vállalatok megfigyelésén alapulnak, kitérnek a vezetô, a szervezeti forma, valamint a menedzselési és monitorozási módszer megválasztásának problémájára is. A vezetók tekinte-

nanotech alapon kölcsönösen szinergisztikus hatást ígérnek. Ezért ma már beszélnek az ún. „konvergens technológiai fejlődésról", ami mindenekeloótt a nanotech, az informatika, a biotechnológia és a kognitív tudomány átfogó technológiai fejlődési iránnyá, múszaki megatrenddé változását jelenti.

${ }^{29}$ Az ilyen vizsgálatok rendszeressé tételét az amerikai NSF (Nemzeti Kutatási Alapítuány) és az USA kereskedelmi minisztériuma kezdeményezte elöször, Bill Clinton ajánlásával. Az Európai Unió 2004-ben követte ezt az tún. CTE KS- (Converging Technologies for the European Knowledge Society) programmal. Például Hollandiában a feltételezhetố társadalmi és környezeti hatások vizsgálata részét képezi a nemzeti nanotech programnak. Fontos észrevenni, hogy mind a szakpolitikai, mind a vállalati menedzselési gondolkodásban lényeges elmozdulás van az ún. „együtt tervezés” felé ahelyett, hogy az innovációs folyamat utolsó fázisában az absztrakt környezetben kifejlesztett innovációval szembeni ellenállás megszüntetését tekintenék „természetes” feladatnak.

${ }^{30}$ A tanulmánynak ez a része a SOCROBUST-projekt kifejlesztésével nyert eredmények kritikai összefoglalása.

Ezt a projektet az EU 4. kutatási keretprogramjának TSER (Targeted Socio-Economic Research) programja keretében 1999 és 2001 között valósították meg. Figyelembe veszem a projekt hatásait és a rá következő diszkusszió eredményeit (vö. Jolivet és mtsai, 2002). 
tében szükségesnek látott képességek felölelik a „karizmatikus vezetô” képességeit is, aki képes olyan új víziókat alkotni, amelyek eléggé vonzóak a csatlakozáshoz, és biztosítani képesek az egy irányban folyó munkát. ${ }^{31}$ Van, aki az olyan, egyszerre többféle irányban is cselekvóképes menedzser képét vázolja fel, aki képes mind a kis, mind az áttörő innovációk menedzselésére, és van, aki azt emeli ki, hogy a vezetônek kiváló esélyfelismerônek, határokat átívelő gondolkodásúnak kell lennie. Hasonló javaslatok vonatkoznak a szükséges szervezeti változtatásokra is: például független szervezeti egységet kell a radikális innováció menedzselésére biztosítani, vagy éppen az egyszerre több irányban is cselekvóképes szervezet felállítása elégítheti ki a radikális innovációk menedzselésének rendszeressé váló igényét, vagy önálló projektfelügyelő bizottságokra vagy sajátos szakértôi team felállítására van szükség.

Aligha vitatható azonban, hogy az igazán centrális kérdés átfogóbb és mélyebb is egyben, s ez a helyes módszer, a dinamikus tervezés problémája. Ez a lényegi bizonytalanságot tartalmazó folyamatokhoz való, változó célú alkalmazkodás menedzselését jelenti. Az ezredfordulóra az irodalom nagyjából egységes volt már abban, hogy ennek alapvetố fontosságú eleme a jó szcenárióalkotás, amelyben azonosíthatók az (adott idôben érzékelt) jövóbeli bizonytalanságok. Egységes volt továbbá abban is, hogy meg kell vizsgálni, milyen lehetôségek és képességek vannak vagy jönnek létre az adott vállalatnál (aktornál) versenyeloónyként e bizonytalanságok menedzselésében. ${ }^{32}$ Végül egység alakult ki abban is, hogy a vizsgálatot periodikusan megismétlődőnek kell elófeltételezni, mivel a trajektória a bizonytalanság miatt nem folytonosnak feltételezendő.

A radikális innovációk megvalósulásának különösen érzékeny pontja az, amit „,kikutatási" fázisnak lehet nevezni. ${ }^{33}$ Ebben a fázisban különösen nagy a bizonytalanság. Ugyanakkor az eddigi menedzselési megfontolások általában a fejlesztési szakasszal foglalkoznak.

A SOCROBUST-projekt elindítását az akkor hozzáférhetố javaslatok három korlátjának korábbi felismerése ösztönözte. Ezeknek a korlátoknak a meghaladására a SOCROBUST-projekt a már említett értékelési eljárás bevezetését javasolta a szokásos támogatásallokációs eljárások helyett. Ez eltérő értékelési eljárás kifejlesztését és ezzel összefüggésben a siker kritériumainak eltérố meghatározását, továbbá a projekt gyakori ellenốrzését követelte meg. (Az eltérés vonatkozásában azt mondhatjuk, hogy a radikális innováció racionális menedzselését elốsegítô értékelési eljárás - a támogatásallokációt megalapozó értékeléssel szemben, ami kívül marad azon, amit támogat - részévé válik a projektnek. $)^{34}$ Megkövetelte továbbá azt is, hogy az értékelók a bizonytalanság megítélésére alkalmas eljárási racionalitás megítélésének képességével rendelkezzenek. Arról van szó, hogy a radikális innovációknak különösen a kikutatási fázisában a költség/haszon számítások helyett sokáig csak jó projektleírásokat és bizonytalanságértékeléseket lehet valószerúen elvégezni. Ezek a feltételezett bizonytalanság körülte-

\footnotetext{
${ }^{31}$ Úgy tû́nik, hogy kevesebb szó esik az irodalomban a munkatársak megkövetelendő tulajdonságairól.

${ }^{32}$ Ilyen versenyelốny lehet a szervezet tanulóképessége, rugalmassága stb.

${ }^{33} \mathrm{Ez}$ a projektmenedzsmentnek valóban a kezdeti fázisa, amikor még az is kérdéses, hogy fel lehet-e állítani valamilyen jól körülhatárolható projektet (Cheng és Van de Ven, 1996).

${ }^{34}$ Ez megjelenhet például tanácsadásban, de akár abban is, hogy az értékelő mélyebben beavatkozik a projekt alakításába bizonyos fázisokban, és együttmúködésük a projekt megvalósítóival koevolúciós jellegưvé válik.
} 
kintő leírásával is csak plauzibilitáshoz és összehasonlításhoz tudnak eljutni. Ezért az eljárási racionalitás megítélése kerül elốtérbe. Ennek megítélésével az értékelés már nem marad a projektre kívülról alkalmazott, hanem visszacsatolódva maga is a víziófejlesztés részévé válik, és jelzéseket ad a lehetséges piacokról, a támogatókról, a fellépó bizonytalanságokról és leküzdésük módjáról, a projekt folytathatóságáról stb. Tehát radikális innováció esetén az értékelés nem csupán a forrásallokáció eldöntésének módja, ami lineáris visszacsatolást valósít meg valamely adott cél elérése érdekében, hanem segítségnyújtás is ahhoz, hogy milyen irányt érdemes követni, és mi legyen a következó sürgetố lépés. Így az értékelés sokszoros és sokdimenziós visszacsatolás.

Ilyen bizonytalan projekteknél a projekt fejlődése során változhat például a részt vevő partnerek száma és egymáshoz való viszonya is. Ugyanis nem lehet kötelezó az (eredeti) partnerek számára annak az útváltozásnak, esetleg célváltozásnak a követése (például eltérố teherviselési képességük, tanulóképességük, régi érdekeikhez való ragaszkodásuk, új érdekeik miatt), ami a lehetséges új bizonytalanságok fellépése következtében a projekt fejlődése során konstruálódik és rekonstruálódik. Mindig a lehetséges bizonytalanságok együttes értékelése kell, hogy irányadó legyen a partnerségre. A harmadik felismert korlát az volt, hogy a gyakorlatban megtalálható esetekben a projektmenedzselés sikere céljából felállított szakértői bizottságok a fejlesztési fázisra koncentráltak, amikor a projektnek már jó esélye volt a fennmaradásra, nem pedig a kikutatási szakaszra, amikor még az is kérdéses volt, hogy mely elemekból állhat össze a projekt. A projekt fejlesztésének fázisában a bizonytalanságmenedzselési projekt sikere sem mérhetố a piaci eredményen, hanem csak azon, hogy tanulás mutatható-e ki a projekt végzése során, s hogy ezzel, mivel fenntartható sémához jut el, létrejön-e a képesség a normális beruházási módra való visszatérésre.

E tanulságok alapján a SOCROBUST-projekt erre az érzékeny szakaszra koncentrált és erre dolgozott ki metodológiát. A feladat arra koncentrálódott, hogy a javasolt áttörố innovációkra releváns leírhatósági módszert alakítsanak ki, ami lehetốvé teszi az orientációt kiszámítható kockázatok hiányában is. Kiindulópontul Bruno Latour eredményeit használták fel, aki a kudarcot vallott projektek elemzése alapján korábban három patológiát azonosított. Ezek az ố terminológiájával élve a következók: a „realizmus hiánya”, a „stratégia hiánya” és a „falszifikálhatóság hiánya”. ${ }^{35}$ Röviden jelzem ezeket a patológiákat, ahogy Latour leírta és a SOCROBUST-projekt átvette óket, hogy kiindulópontul szolgáljanak saját eljárásuk kidolgozására. Latour szerint a projektekhez megalkotóik általában úgy állnak hozzá, hogy abból hiányzik a „realizmus”, azaz feltételezik annak magasabbrendúségét, mind a megoldás, mind a hozzá vezető út vonatkozásában. Ezért eltekintenek attól, hogy tekintettel legyenek a lehetséges felhasználókra. A PROTEE-projekt ezért azt javasolta, hogy fejlesszenek ki a projekt „beírásán” (script) alapuló deszkriptorokat, hogy kimutassák a projekt gazdagságát az alternatívák megengedésében, továbbá azért, hogy azonosítsák a bizonytalanságokat és a projekt flexibilitását, vagy - ami a fordított nézőpontból ugyanaz - annak irreverzibilitását („kötelezó áthaladási pontjait"), a heterogén hálómodell szempontjából kifejezve. A második patológia a „stratégia hiánya” vagy a „paranoia”. Ez abból áll, hogy a projekt védelmezói

${ }^{35}$ Latour, Bruno 2000. Latour nézeteinek összefoglalása elérhetố az interneten a SOCROBUST-projekt zárójelentésében. 
képtelenek az ellenkezók nézeteinek abszorbeálására, mivel azok, szerintük, irracionálisak. A probléma menedzselésére bevezetendố stratégiának lehetôvé kellene tennie, hogy a projekt legalább valamennyire vitatható legyen, legyen abszorpciós kapacitása és átalakítható legyen, hogy az opponensek álláspontja is megjelenhessen benne. Nyilvánvaló, hogy ez megköveteli a projekt magjának azonosítását, amitól nem lehet eltekinteni. E mag sajátosságai lesznek döntốek ebben a vonatkozásban. A kifejlesztendő deszkriptorok célja az, hogy leírják, mi jellemzi a projektet ebból a szempontból. A harmadik patológia a „zártság” (closeness) vagy falszifikálhatatlanság. Ez abban áll, hogy az innovátorok megkísérlik, hogy a saját technikai világukban maradjanak, kizárják azt, hogy a projektet más szakértók átfogalmazzák stb. Ugyanakkor a sikeres projektmenedzseléshez, a bizonytalanságok területének azonosításához és a projekt lehetséges transzlációinak javasolásához szükség van a szakértôi munka heterogenitásának biztosítására.

Miból áll a SOCROBUST-projekt által javasolt menedzsmenteljárás? Ez iteratív eljárás, amely négy „lépés” és 10 „,eszköz” alkalmazását jelenti. ${ }^{36}$ A menedzselés alapvető lépései a következók: A kiinduló lépés a projekt jelenlegi helyzetének, a projekt fennálló technikai-gazdasági hálójának a felmérése, azokra az aktorokra helyezett hangsúllyal, amelyek ebben a fázisban résztvevói a projektnek. ${ }^{37}$ Ezt állítják szembe a kialakított jövóképpel, az elérendő technikai-gazdasági hálóval, feltételezve, hogy a projekt sikerült, elérte a céljait. Ez segít abban, hogy minden fázisban új, kritikus aktorokat azonosítsanak, amelyeknek a bevonása elengedhetetlen. A második lépésben visszatekintés következik abból a célból, hogy azonosítsák azokat a döntố változásokat, amelyek szükségesek ahhoz, hogy a feltételezett jövókép megvalósuljon. Ilyenek lehetnek például új eljárások, amelyeket meg kell valósítani, régi eljárások, amelyektól meg kell szabadulni, továbbá az olyan kérdésekre adható válaszok, hogy szükség van-e ehhez új aktorokra, változtatni kell-e a meglevő háló felépítésén, mennyire kell érzékenynek lenni negatív jelzésekre, ki van-e dolgozva a korai figyelmeztetés rendszere stb. A harmadik lépésben kontextusba helyezik az azonosított kulcsváltozásokat, amelyeket meg kell valósítani abból a célból, hogy életrevalóságukat ellenórizzék az adott kontextusban. ${ }^{38}$ Ekkor minden kulcsváltozásra nézve fel kell becsülni, hogy mennyire „képessé tevó" (enabling) vagy korlátozó a közeg, ami az adott intermedier szakaszban úgy túnik, hogy fennáll, s ennek megfelelően milyen irányt kell venni. Ez a múvelet lehetốvé teszi, hogy felbecsüljék és értékeljék a projekt mindenkori helyzetét és azt, hogy milyen kulcselőfeltevésektól függ. A negyedik lépésben azonosítják mindazokat a plauzibilis

\footnotetext{
${ }^{36}$ Ilyen eszköz például a projekt ,jelenlegi világának” és ,jövóbeli világának” azonosítása, továbbá a kritikus aktorok vagy a kulcsfontosságú változások táblázata.

${ }^{37}$ A hálóelemzés megmutatja, hogy mely aktorok vesznek részt a projektben, azok hogyan pozicionáltak, hogyan viszonyulnak egymáshoz, milyen átmeneti kapcsolatok kötik óket össze, kik a lehetséges versenytársak, melyek a gyenge pontok, milyen döntések történtek már meg, amelyek bizonyos irreverzibilitást visznek a rendszerbe stb.

${ }^{38}$ Már említettem, hogy az áttöró innovációnak három dimenzióját szokták sematikusan megkülönböztetni. Ezek a mûszaki dimenzió, az infrastrukturális (törvényi, adminisztratív) dimenzió és a stakeholderek közötti viszony, valamint a termelók és a fogyasztók közötti viszony dimenziója. Ezek együttesen képeznek elégséges feltételt az innováció megvalósulására. Ezek mentén gondolandó végig, hogy milyen képessége van az adott vállalatnak, illetve projektnek a piaci részesedés megváltoztatására.
} 
lépéseket, amelyeknek meg kell valósulniuk, továbbá tisztázzák, hogy a menedzsment mely lépéseket látszik képesnek befolyásolni. Ebben a lépésben döntik el, hogy van-e és milyen kapacitása a projektnek arra, hogy az azonosított kulcsváltozásokat megvalósítsa, és sor kerül a lehetségesnek ítélt változások monitorozott véghezvitelére. Különösen fontos itt a kollektív egyetértés, hogy megnövelje a cselekvés sikerének a valószínúségét. Itt kap különös jelentôséget piaci viszonyok között a gazdaságban, demokratikus politikai viszonyok között a politikai innováció területén, hogy létrejön-e olyan széles körú támogató fórum, amely lehetốvé teszi a cselekvés és a kimenet társadalmi robusztusságának növelését. A robusztusság növelését lehetôvé tevő technika alapvetôen széles körú társadalmi vita kialakítását és fenntartását jelenti.

A folyamat elengedhetetlen része a magasabbrendú tanulás (kiterjesztett tanulás vagy keretreflektív tanulás $)^{39}$ megvalósítása, hiszen szükség lehet, akár többször is, a célok megváltoztatására a folyamat elốrehaladása során, sốt mi több, a környezet módosításának elérése is szükségessé válhat. Ha sikerre vezetnek a kezdeti véletlen próbálkozások a bizonytalanság iteratív menedzselésére tett erôfeszítések folyamatában, akkor önszervezố rendszer fejlődik ki, és a folyamat stabilizálódó, robusztus sémához vezet el. Ezzel új út keletkezik, amelyen a folyamat természetesnek túnó, kiszámítható módon folytatódik addig, amíg belső vagy külső eredeti meglepetések nem lépnek fel. Fontos észrevenni, hogy radikális innovációknál többról van szó, mint pusztán egy belsố menedzselési feladat végrehajtásáról. Mint már utaltam rá, radikális innováció csak akkor tud valóban létrejönni, ha egy „képessé tevô” (enabling) infrastruktúra is létrejön körülötte, amely magában foglalja azokat a külsố feltételeket, kompetens felhasználókat, adekvát társadalmi értékeket, jogi szabályozást stb., amelyek nélkül a legígéretesebb radikális innováció sem valósulhat meg.

Az egyik elem, amivel a SOCROBUST-módszer különösen úttörố próbálkozásként jelent meg néhány éve, az volt, hogy a diszkussziós fórum létrehozásával lehetôvé tette a projekt intermedier szakaszában, hogy a lehetô legszélesebb körben kooperatívan jöjjön létre a megcélzott radikális innováció, hogy az a lehető legszélesebb alapokra támaszkodva legyen társadalmilag robusztus. Ezzel pedig megelôzhető az a „kész” innováció esetében mintegy sorsszerúségként fellépố probléma, hogy azt a vele váratlanul szembekerülő társadalom idegenként fogadja, és ellenállással reagáljon rá. ${ }^{40} \mathrm{Nem}$ nehéz belátni, hogy a

\footnotetext{
${ }^{39}$ Kiterjesztett tanulás esetén nemcsak azt értjük meg, hogy a cselekvés és a kimeneti viszonyok hogyan változnak, hanem azt is, hogyan jön létre az az elôzetes tudás, melynek alapján feltételezzük, hogy mi képez alternatív cselekvést, kimenetet és kontextust. Azt mondhatjuk, hogy a kiterjesztett tanulás keretreflektív, az előfeltevések megítélésére támaszkodó tanulás, azaz intelligencia, ami lényeges új célt, utat, eszközöket stb. mutathat ki. Radikális innováció során többszörösen is sor kerülhet arra, hogy ilyen tanulásra legyen szükség.

${ }^{40}$ Nem tartható véletlennek, hogy a SOCROBUST-metodológia kedvező fogadtatására a 90-es években lezajlott nagyobb válságok ( $B S E$-válság, $G M O$-válság) megtapasztalása után került sor. Különféle vállalatok és közigazgatási apparátusok tanulási tapasztalatai azt mutatják ebben a vonatkozásban, hogy a válságok talán megelốzhetốk, ha a megfelelố diskurzus felépítése, megvalósítása után a radikális innováció megvalósulásához szükséges hálók (különösen a termelói-fogyasztói háló) kialakulnak a radikális innováció körül, s ez megfelelốen reprezentálódik magában a radikális innovációban. Fontos példa ebból a szempontból, ahogy az Unilever ma elốzetes diskurzust alakít ki az állati fehérjék élelmiszerekben mesterségesen elōállított fehérjékkel való helyettesítésének lehetséges fogyasztói fogadtatásáról. Hasonló diskurzusok megjelenése valószínúleg egyre tipikusabb lesz. A radikális innovációk ugyanis olyan területekre lépnek, amelyek eddig nemcsak természet adta jellegúek voltak („gyümölcs az, ami a fán terem”), hanem ilyenként való létezésük társadalmi
} 
radikális innovációk egyre gyakoribbá válásával a korábbi inno- vációfejlesztési módszer továbbélése esetén az ellenállás egyre gyakoribbá válásával is számolni kell.

A SOCROBUST-módszer alapvetô innovációt valósít meg a szükséges eloórelátás kidolgozásában is. A jövóképalkotás szokásos technikája helyett ugyanis az ún. „belsô jövóképre", a projekt saját jövóképére koncentrál, arra, hogy valamely adott végcél elérése milyen „beírást” (script) tartalmaz a projektmenedzselés előzó fázisaira. ${ }^{41}$ Ahogy M. Akrisch a terminust bevezette, a „beírás” azon szükségszerú elemek együttese, amelyeknek a megvalósulása nélkül az adott projektben meghatározott jövókép biztosan nem valósulhat meg. Így ezek létrehozatala a projekt számára „kötelező áthaladási pontot" (obligatory passage point) képez. A projekt sikerét ez a gondolkodásmód így döntốen attól teszi függốvé, hogy az képes-e azokon a „kötelezó áthaladási pontokon” átjutni, amelyek végcéljából adódnak. A heterogén hálók képzốdésében való gondolkodásnak alapvető eleme a koncentrálás a jövókép alkotásának erre a mozzanatára. Fontos megjegyezni, hogy a radikális innováció menedzselésére kialakított módszer lehetôvé teszi, hogy valamely adott innovációs projekt iteratív módon valósuljon meg vagy jól érvelhetốen adja át más célú projektnek a helyét. Ezzel menedzselési racionalitást valósít meg, de csak nagyon korlátozottan szolgáltat menedzselési technikát bármely radikális innováció menedzselésére.

Áttekintettem a globalizáció körülményei között az innovációról való gondolkodás valószerú és konzekvens elméleti megalapozásának fóbb alapvonásait. Ez a gondolkodásmód dinamikus rendszerszemlélet és evolucionista gondolkodás érvényesítését jelenti. Kiegészítésként az elmondottakat illusztráltam a radikális innováció menedzselésére javasolt, kipróbált módszerrel. Ez a módszer lehetővé teszi, hogy racionálisan viszonyuljunk a menedzselési feladatokhoz lényegi bizonytalanság esetén is.

\section{Irodalom}

Akrich, Madeleine (1992): The De-scription of technical objects. In Bijker, Wiebe - Law, John (eds.): Shaping Technology/Building Society: Studies in Sociotechnical Change. Cambridge MA.: MIT Press.

Allen, Peter M. (1993): Evolution: Persistent Ignorance form Continual Learning, In. Day, R. H. Chen, P. (eds.): Nonlinear Dynamics and Evolutionary Economics. Oxford: Oxford Univ. Press.

Cheng, Y. T. - Van de Ven, A. H. (1996): Learning the Innovation Journey: Order out of chaos. Organization Science, 7, 6.

Constant II., Edward W. (1980): The Origins of the Turbojet Revolution. Baltimore: The Johns Hopkins University Press.

ráerôsítést is kapott, például vallási megerôsítéssel, vagy egyszerüen az adott területnek normatíve tulajdonított természetességgel. (Tipikus példákat szolgáltatnak erre a mai genetikai forradalom eredményeinek változatos alkalmazásai és napról napra megjelenô új alkalmazási lehetôségei, különös tekintettel a különbözô klónozási lehetốségek értelme körül folyó vitákra.)

${ }^{41}$ Akrisch, Madeleine, 1992. Bármely jövốkép ugyanis szükségszerúen tartalmaz ilyen belsố „beírásokat”, „kötelezố áthaladási pontokat”, azaz nem valósítható meg bármilyen úton. Ezt tudják és alkalmazzák intuitívan egy nagyon leszúkített alternatívamezố esetén a mindennapi életben azok a szülók, akik a gyerek felkészítését az egyetemre már óvodáskorában elkezdik, s periodikusan értékelik a különösen érzékeny „kötelezô áthaladási pontokat”. 
Giovanni Dosi (1988): The nature of the innovative process. In Dosi, Giovanni et al. (eds.): Technical Change and Economic Theory. London-New York: Pinter.

Lundwall, Bengt-Ake - Boras, Susana (2004): Science, Technology and Innovation Policy. In Jan, Fagerberg - Mowery, David C. - Nelson, Richard: The Oxford Handbook of Innovation. Oxford: Oxford University Press.

Hronszky Imre: Az innováció és a „régi-új” társadalomgazdaság. In Hronszky Imre - Szegó Szilvia - Tóth Attiláné (szerk.) (2001): Innovativ társadalomgazdaság és jövoótudat. Budapest: Arisztotelész Bt.

Hronszky Imre (2002): Kockázat és innováció. A technika fejlódése társadalmi kontextusban. Arisztotelész Kiadó. Intrinszik komplexitásnövekedés és glokalizáció, Közgazdaságtan és innováció fejezetek.

Hronszky, Imre (2005a): Mapping and Managing Uncertainty and Indeterminacy in Future Society-Technology Relations. In Banse, Gerhard - Hronszky, Imre - Nelson, Gordon (eds.): Rationality in an Uncertain World. Berlin: Sigma.

Hronszky, Imre (2005b): Parallelities in Participatory Approaches in Production and Public Administration. In Rohracher, H. (ed.): User Involvement in Innovation Processes, Strategies and Limitations from a Socio-Technical Perspective. München-Wien: Piper.

Hronszky, Imre (2006a): How to Educate Engineers to Become „Reflective Practitioners”? In Ginsztler, János (ed.): Presentations, $7^{\text {th }}$ WFEO World Congress on Engineering Education, „Mobility of Engineers". Budapest: Logod Bt.

Hronszky, Imre (2006b): Is facing engineering education basic new requirements? In Kronwachs, Klaus - Hronszky, Imre (eds.): Shaping Better Technologies. Münster: Litt Verl.

Jolivet, Eric - Laredo, Philippe - Shove, Elizabeth (2002): Managing breakthrough innovations: the SOCROBUST methodology. Paris: Ecole de Mines.

Laredo, Philippe et al. (2002): Final Report of the SOCROBUST Project. Paris: Ecole de Mines. www.ensmp.fr

Latour, Bruno (2000): PROTEE Principles: Theoretical Background. In Duret, Michael et al. (2000): Final Report of the PROTEE Project. Paris.

Lundwall, Bengt-Ake - Boras, Susanna (szerk.) (1997): The Globalising Learning Economy, Implications for Innovation Policy. TSER Programme Report, EC DG XIII. Brussels.

Roco, M. C. - Bainbridge, W. S (2003): Converging Technologies to Improve Human Performance. Dordrecht.

Stirling, Andy (ed.) (1999): On Science and Precaution in THE Management of Technological Risk, VI. A Synthesis report of case studies ESTO project. Luxembourg. 